\title{
Stunting Determinant on Toddler Age of 12-24 Months in Singaparna Public Health Center Tasikmalaya Regency
}

\author{
Erwina Sumartini, ${ }^{1,2}$ Dida Akhmad Gurnida, ${ }^{3}$ Eddy Fadlyana, ${ }^{3}$ \\ Hadi Susiarno, ${ }^{4}$ Kusnandi Rusmil, ${ }^{3}$ Jusuf Sulaeman Effendi ${ }^{4}$ \\ ${ }^{1}$ Midwifery Master Study Program, Faculty of Medicine, Universitas Padjadjaran, Bandung, Indonesia, \\ ${ }^{2}$ Diploma 3 Midwifery Study Program, STIKes Respati, Tasikmalaya, Indonesia, ${ }^{3}$ Department of Child Health, \\ Faculty of Medicine, Universitas Padjadjaran/Dr. Hasan Sadikin General Hospital, Bandung, Indonesia, \\ ${ }_{4}^{4}$ epartment of Obstetrics and Gynecology, Faculty of Medicine, Universitas Padjadjaran/ \\ Dr. Hasan Sadikin General Hospital, Bandung, Indonesia
}

\begin{abstract}
Stunting is a physical growth failure condition signed by height based on age under -2SD. The research goal is knowing the dominant factor associated with stunting on toddler age of 12-24 months in the working area of Singaparna Public Health Center Tasikmalaya regency. The research applies to the cross-sectional design of gender, weight, exclusive breastfeeding history, completeness immunization, and clinically healthy variables, while casecontrol is for nutrition intake variable. The sample was a total sampling of 376 toddlers, then 30 for case and control group with the simple random method from December 2017 to February 2018. The instrument is a questionnaire, food frequency questionnaire (FFQ), and infantometer. Data analyzed in several ways; univariable, bivariable with chi-square, and multivariable with logistic regression. Research result shows stunting prevalence was $22.5 \%$, next pertain factor of stunting are gender $(\mathrm{POR}=0.564,95 \% \mathrm{CI}=0.339-0.937, \mathrm{p}$ value $=0.011)$, exclusive breastfeeding giving history $(\mathrm{POR}=1.46,95 \% \mathrm{CI}=1.00-2.14$, $\mathrm{p}$ value $=0.046)$, and clinically health $(\mathrm{POR}=1.47,95 \% \mathrm{CI}=1.00-2.16$, $\mathrm{p}$ value $=0.044)$. Moreover, dominant factor were gender $(\mathrm{OR}=0.56,95 \% \mathrm{CI}=0.339-0.937, \mathrm{p}$ value $=0.027)$ and clinically health $(\mathrm{OR}=1.68,95 \% \mathrm{CI}=1.022-2.771$, p value $=0.041)$. Thus, gender and clinical health are stunting determinant factors. Children's health should increase to create maximum growth.
\end{abstract}

Key words: Exclusive breastfeeding, gender, nutrition intake, stunting

\section{Determinan Stunting pada Anak Usia 12-24 Bulan di Puskesmas Singaparna Kabupaten Tasikmalaya}

\begin{abstract}
Abstrak
Stunting merupakan kondisi kegagalan pertumbuhan fisik yang ditandai dengan tinggi badan menurut usia berada di bawah -2SD. Penelitian ini bertujuan mengetahui faktor determinan stunting pada anak usia 12-24 bulan di wilayah kerja Puskesmas Singaparna Kabupaten Tasikmalaya. Penelitian menggunakan desain cross-sectional untuk variabel jenis kelamin, berat badan lahir, riwayat ASI eksklusif, kelengkapan imunisasi, dan sehat secara klinis, sedangkan desain case-control untuk variabel asupan nutrisi. Pengambilan sampel secara total sampling sejumlah 376 anak, selanjutnya diambil 30 anak untuk kelompok kasus dan kontrol dengan metode random sederhana periode Desember 2017 hingga Februari 2018. Instrumen menggunakan kuesioner, food frequency questionaire (FFQ), dan infantometer. Analisis data dilakukan secara univariabel, bivariabel dengan chi-square, dan multivariabel dengan regresi logistik. Hasil penelitian menunjukkan prevalensi stunting sebesar 22,6\%, faktor yang berhubungan dengan stunting di antaranya jenis kelamin $(P O R=0,564 ;$ IK95\%=0,339-0,937; $p=0,011)$, riwayat pemberian ASI eksklusif ( $\mathrm{POR}=1,46$; IK95\%=1,00-2,14, $\mathrm{p}=0,046)$, dan sehat secara klinis $(\mathrm{POR}=1,47$; $\mathrm{IK} 95 \%=1,00-2,16 ; \mathrm{p}=0,044)$. Faktor dominan yang berhubungan dengan stunting adalah jenis kelamin $(\mathrm{OR}=0,56$; $\mathrm{IK} 95 \%=0,339-0,937 ; \mathrm{p}=0,027)$ dan sehat secara klinis $(\mathrm{OR}=1,68 ; \mathrm{IK} 95 \%=1,022-2,771 ; \mathrm{p}=0,041)$. Jenis kelamin dan sehat secara klinis merupakan faktor determinan stunting. Kesehatan anak perlu ditingkatkan untuk menciptakan pertumbuhan anak yang maksimal.
\end{abstract}

Kata kunci: ASI eksklusif, asupan nutrisi, jenis kelamin, stunting

Received: 11 April 2018; Revised: 29 October 2019; Accepted: 26 December 2019; Published: 31 December 2019

Correspondence: Erwina Sumartini, S.S.T., M.Keb. Diploma 3 Midwifery Study Program, STIKes Respati. Jln. Singaparna km 11, Cikunir, Singaparna, Tasikmalaya 46181, West Java, Indonesia. E-mail: erwinasumartini5@gmail.com 


\section{Introduction}

Growth is a continuous process that starts from conception until adult. Stunting is one of the physical growth failure condition signed by height based on age. Stunting occurs when height by age based on $\mathrm{z}$ score $<-2 \mathrm{SD}$ and severe stunting if $\mathrm{z}$ score $<-3$ SD. ${ }^{1-3}$ Stunting occurs as an impact of chronic malnutrition during 1,000 first days of life. It is such a predictor of inadequate human resources, and then it decreases a nation's productive ability in the future. Besides that, they face some more significant possibilities to live as an adult with less education, weak, unhealthy, and more susceptible to getting a non-contagious disease such as obesity, hypertension, and diabetes. ${ }^{4-6}$

Gender, birth weight, breastfeeding history, nutrition intake, immunization, and clinical health are the immediate cause of a child's malnutrition. ${ }^{7}$

Tasikmalaya regency includes the four regions with bad nutrition status in the high category. Stunting toddler prevalence of Tasikmalaya regency in 2016 was $41.73 \%$, wasting $15.6 \%$, and obesity was $8.65 \% .^{8-11}$ Singaparna Public Health Center Tasikmalaya regency has some problems associates with nutrition. In 2016, the stunting toddler was 672 people (17.2\%) dan severely stunting was 245 people (6.3\%) from all of the toddlers in the working area of Singaparna Public Health Center. Moreover, in Tasikmalaya regency, low birth weight places as first grade (7.15\%) and has low exclusive breastfeeding with only $(38.11 \%) .{ }^{10,11}$ The research goal is knowing the dominant factor associates with stunting on toddler age of 12-24 months in the working area of Singaparna Public Health Center.

\section{Methods}

The research applies observational analytic using two research designs; the cross-sectional design used to review variables of gender, birth weight, exclusive breastfeeding history, complete immunization, and clinical health. Case-control design applies to review nutrition intake variable that involves protein and energy intake. Casecontrol design implemented after finding cases and control groups from the result of the crosssectional design. The target population in this research is the entire toddler age of 12-24 months that live in the working area surrounding Singaparna Public Health Center of Tasikmalaya regency from December 2017 to February 2018.

A total sampling of 376 toddlers used for the first stage. While stage II with the case-control design, used 30 respondents in each group using simple random sampling. Inclusion criteria in this research were toddler age of 12-24 months (the preterm baby history age decided by age correction), healthy, no congenital abnormality, and get parent's agreement.

The research instrument was questionnaires, food frequency questionnaires (FFQ), and infantometer with an accuracy level of $0.1 \mathrm{~cm}$. Data analyzed using the chi-square test and logistic regression analysis.

The research was conducted after obtaining ethical approval from the Health Research Ethics Committee of the Faculty of Medicine of Universitas Padjadjaran with letter number: 1112/ UN6.C10/PN/2017. We also had permission from the National Unity and Community Protection Agency (Kesatuan Bangsa dan Perlindungan Masyarakat/Kesbanglinmas) of Tasikmalaya Regency, Tasikmalaya Regency Public Health Office, and Singaparna Public Health Center.

\section{Results}

Stunting prevalence on toddler age of 12-24 months had presented in the form of a frequency distribution table (Table 1).

Based on Table 2 can be seen that child's age factor had a significant correlation with stunting. It means the toddler age of 19-24 months has stunting risk 1.12 times bigger than toddler age of 12-18 months. A child's gender has a significant correlation with stunting. It means males had stunting risk 1.65 times bigger than females. Next, breastfeeding giving history has a significant correlation with stunting. It reflects non-exclusive breastfeeding toddlers may have a risk of 1.46 times bigger than the exclusive one.

Table 1 Stunting Case on Toddler Age of 12-24 Months in Working Area of Singaparna Public Health Center Tasikmalaya Regency

\begin{tabular}{lcc}
\hline Stunting Case & $\mathbf{n = 3 7 6}$ & Percentage \\
\hline Severely stunting & 18 & 4.8 \\
Stunting & 67 & 17.8 \\
Non-stunting & 291 & 77.4 \\
\hline Note: stunting prevalence $(95 \% \mathrm{CI})=\mathbf{2 2 . 6 \%}(18.7-27.1 \%)$
\end{tabular}


Table 2 The Factor Associated with Stunting Case on Toddler Age of 12-24 Months in Working Area of Singaparna Public Health Center Tasikmalaya Regency

\begin{tabular}{|c|c|c|c|c|}
\hline \multirow{2}{*}{ Studied Factor } & \multicolumn{2}{|c|}{ Stunting Case $(n=376)$} & \multirow{2}{*}{ p Value } & \multirow{2}{*}{ POR (95\%CI) } \\
\hline & Stunting & Non-stunting & & \\
\hline Child's age (months) & & & $0.035^{*}$ & \\
\hline $12-18$ & 42 & 181 & & 1.0 \\
\hline $19-24$ & 43 & 110 & & $1.12(1.00-1.27)$ \\
\hline Father's age (years) & & & $0.673^{*}$ & \\
\hline $20-35$ & 46 & 165 & & 1.0 \\
\hline$>35$ & 39 & 126 & & $0.92(0.63-1.34)$ \\
\hline Father's education & & & $0.285^{*}$ & \\
\hline Elementary & 33 & 97 & & $1.93(0.81-4.60)$ \\
\hline Senior & 47 & 161 & & $1.72(0.73-4.03)$ \\
\hline University & 5 & 33 & & 1.0 \\
\hline Father's job & & & $0.682^{*}$ & \\
\hline Employee & 13 & 50 & & 1.0 \\
\hline Freelancer & 72 & 241 & & $1.03(0.89-1.18)$ \\
\hline Mother's age (years) & & & $0.172^{*}$ & \\
\hline$<20$ & 2 & 9 & & 1.0 \\
\hline $20-35$ & 60 & 230 & & $1.03(0.78-1.37)$ \\
\hline$>35$ & 23 & 52 & & $1.18(0.86-1.62)$ \\
\hline Mother's education & & & $0.397^{*}$ & \\
\hline Elementry & 31 & 88 & & $0.98(0.52-1.86)$ \\
\hline Senior & 45 & 178 & & $0.76(0.41-1.41)$ \\
\hline University & 9 & 25 & & 1.0 \\
\hline Mother's job & & & $0.601^{* * *}$ & \\
\hline Employed & 6 & 16 & & $1.22(0.60-2.48)$ \\
\hline Unemployed & 79 & 275 & & 1.0 \\
\hline Gender & & & $0.011^{*}$ & \\
\hline Male & 54 & 139 & & $1.65(1.11-2.44)$ \\
\hline Female & 31 & 152 & & 1.0 \\
\hline Birth weight & & & $0.632^{*}$ & \\
\hline Low & 10 & 29 & & $0.95(0.78-1.16)$ \\
\hline Normal & 75 & 262 & & 1.0 \\
\hline Breastfeeding history & & & $0.046^{*}$ & \\
\hline Exclusive & 36 & 159 & & 1.0 \\
\hline Non Exclusive & 49 & 132 & & $1.46(1.00-2.14)$ \\
\hline Immunization completeness & & & $0.376^{*}$ & \\
\hline Complete & 75 & 266 & & 1.0 \\
\hline Incomplete & 10 & 25 & & $1.29(0.74-2.27)$ \\
\hline Clinically healthy & & & $0.044^{*}$ & \\
\hline Yes & 35 & 156 & & 1.0 \\
\hline No & 50 & 135 & & $1.47(1.00-2.16)$ \\
\hline
\end{tabular}

Note: "chi-square test in significance level, "*Fisher's exact test in significance level $5 \%$

Also, clinically health has a significant correlation with stunting. It showed the clinically unhealthy toddler possibly gets a risk 1.47 times to be stunting rather than the healthy one.

Table 3 shows a significant correlation between gender and stunting with $\mathrm{OR}$ value $=0.56$
$(95 \% \mathrm{CI}=0.339-0.937)$ and $\mathrm{p}$ value $=0.027$; this means males had a higher risk of 0.56 times than females, gender was the most dominant factor pertain to stunting. Moreover, there was another significant correlation on the variable of clinically healthy toddlers and stunting, pointed 
Table 3 Stunting Determinant Factor on Toddler Age of 12-24 Months in Working Area of Singaparna Public Health Center Tasikmalaya Regency

\begin{tabular}{lcccc}
\hline Variables & $\begin{array}{c}\boldsymbol{\beta} \\
\text { Coefficients }\end{array}$ & SE $\boldsymbol{\beta}$ & $\begin{array}{c}\mathbf{p} \\
\text { Value }\end{array}$ & $\begin{array}{c}\text { Adjusted Odds Ratio } \\
\text { (95\%CI) }\end{array}$ \\
\hline First model & & & & \\
$\quad$ Gender & -0.581 & 0.262 & 0.026 & $0.559(0.335-0934)$ \\
Child's age & 0.443 & 0.257 & 0.085 & $1.557(0.940-2.578)$ \\
$\quad$ Breastfeeding history & 0.414 & 0.258 & 0.109 & $1.513(0.912-2.509)$ \\
Clinically healthy & 0.547 & 0.257 & 0.033 & $1.729(1.046-2.858)$ \\
$\quad$ Mother's age (1) & 0.096 & 0.821 & 0.014 & $1.101(0.220-5.497)$ \\
$\quad$ Mother's age (2) & 0.613 & 0.849 & 0.470 & $1.846(0.350-9.740)$ \\
Final model & & & & \\
Gender (male) & -0.573 & 0.260 & 0.027 & $0.564(0.339-0.937)$ \\
Child's age (19-24 months) & 0.455 & 0.254 & 0.074 & $1.575(0.957-2.592)$ \\
$\quad$ Breastfeeding (non-exclusive) & 0.446 & 0.224 & 0.079 & $1.563(0.949-2.573)$ \\
$\quad$ Clinically healthy (no) & 0.520 & 0.255 & 0.041 & $1.683(1.022-2.771)$ \\
\hline Note: model accuracy=77.4\% & & & &
\end{tabular}

Note: model accuracy $=77.4 \%$

Table 4 The Correlation between Nutrition Intake and Stunting on Toddler Age of 1224 Months in Working Area of Singaparna Public Health Center Tasikmalaya Regency

\begin{tabular}{lccccc}
\hline Nutrition Intake & $\begin{array}{c}\text { Stunting } \\
(\mathbf{n = 3 0 )}\end{array}$ & $\begin{array}{c}\text { Non-stunting } \\
(\mathbf{n = 3 0 )}\end{array}$ & $\begin{array}{c}\text { Total } \\
(\mathbf{n = 6 0})\end{array}$ & $\begin{array}{c}\mathbf{p} \\
\text { Value }^{*}\end{array}$ & $\begin{array}{c}\text { OR } \\
(\mathbf{9 5 \%} \text { CI) }\end{array}$ \\
\hline Energy & & & & 0.347 & \\
$\quad$ Adequate ( $\geq 80 \%$ RDA) & 25 & 22 & 47 & & $0.55(0.15-1.93)$ \\
Less (<80\% RDA) & 5 & 8 & 13 & & 1.0 \\
Protein & & & & 0.688 & \\
$\quad$ Adequate ( $\geq 80 \%$ RDA) & 27 & 26 & 53 & & $0.72(0.14-3.54)$ \\
$\quad$ Less (<80\% RDA) & 3 & 4 & 7 & & 1.0 \\
\hline Note: "chi-square test in significant level 5\%, RDA=recommended dietary allowance (angka kecukupan gizi/AKG)
\end{tabular}

by $\mathrm{OR}$ value $=1.68(95 \% \mathrm{CI}=1.022-2.771)$ and $\mathrm{p}$ value $<0.041$.

Stage 2 analyzed between nutrition intake and stunting, energy, and protein intake presented in Table 4. Tabel 4 reflects there was no significant correlation between energy intake and stunting with $\mathrm{p}$ value $=0.347$, also no significant correlation between protein and stunting with $\mathrm{p}$ value $=0.68$.

\section{Discussion}

Stunting prevalence on toddler age of 12-24 months in the working area of Singaparna Public Health Center Tasikmalaya regency reaches 22.6\%. This percentage exceeds the limit of WHO non-public health of $20 \%$. Based on the $\mathrm{z}$ score, the sample that includes the stunting category was 67 children (17.8\%), severely stunting was 18 children (4.8\%), and the normal was 291 (77.4\%).
Stunting prevalence gets higher in the age category of $19-24$ months is 43 of 85 (28.1\%) than $12-8$ months category, $18.8 \%$. Based on the statistical analysis result, the child's age of 1924 months category has a more significant risk of experiencing stunting than the age of 12-18 months with $\mathrm{POR}=1.12(95 \% \mathrm{CI}=1.00-1.27)$ and $\mathrm{p}$ value $=0.035$, this means child's age correlates with stunting. Plus, age of 19-24 months technically experience stunting risk 1.12 times bigger than the age of 12-18 months; the older their age, the higher stunting risk will be.

There was a significant correlation between gender and stunting with $\mathrm{p}$ value $=0.011$. A boy had risk 1.65 much more than a girl. Previous research in Mozambique shows stunting on boy o-59 months was higher than a girl; the boy has stunting chance 4.01 times higher than the girl. ${ }^{12,13}$

Gender becomes a stunting predictor on 
toddler age of 6-23 months when a male has a bigger chance of experiencing stunting than female. Probably, this can happen because a tendency of a male to possess physical activity is higher than female so that he produces much energy that must use to increase the growth. Universal, culturally, the female is predicted less active, just staying at home with her mother, also closer to her meal preparation. ${ }^{12,13}$

The low birth weight (LBW) caused by prematurity and delayed fetal growth. In premature infants, the process of fetal growth in the uterus does not have interference, but low birth weight infants due to birth prematurely and weight according to gestational age. In infants with intrauterine growth restriction (IUGR), there was fetal failure to achieve full growth potential. Thus, infants in this group had a 2.9 percent higher risk of experiencing a slower rate of increment compared with premature infants. ${ }^{14,15}$

In this study found 39 research subjects who had a birth history of LBW, as many as $56.41 \%$ were born with premature and $43.59 \%$ with IUGR. Of the 39 subjects who had a history of LBW, 23 were in clinical health, 16 were in clinically unhealthy conditions. There was a difference in the proportion of unfortunate occurrences in the study subjects, mostly in clinical health. It concluded that the health condition of children is an essential factor to maximize the growth of children with a history of low birth weight.

The results of statistical analysis showed that there was a correlation between the history of exclusive breastfeeding and stunting with $\mathrm{p}$ value $=0.046$. Children with a non-exclusive breastfeeding history are 1.46 times more likely to have stunting compared with exclusively breastfed children.

Based on the results of the study, 49 of 181 (27.1\%) of stunting children were not exclusively breastfed, the results of this study were in line with the results of a study conducted in Ecuador showing that $30 \%$ of stunting children were breastfed less than six months. ${ }^{16}$

Exclusive breastfeeding is breast milk given to infants from birth to six months of age, without adding and replacing with other foods or beverages (except drugs, vitamins, and minerals). Breast milk contains both macro and micronutrient components. Breast milk contains more whey protein that is more subtle and easily absorbed by the baby's intestine compared to cow milk that contains more casein proteins that are more difficult to digest by the baby's intestines. Breast milk has a complete type of amino acid than cow's milk. Breast milk also contains nucleotides compared to cow's milk that has these nutrients in small amounts. Nucleotides play a role in improving the growth and maturation of the intestines, stimulating the growth of good bacteria in the intestines, and increasing iron absorption and immunity to minimize the occurrence of illness in children. Besides, children with exclusive breastfeeding get colostrum which is the perfect food for newborns because of high nutritional value, and full of antibodies that protect infants against infection. ${ }^{17,18}$

The research results showed that there were several reasons for exclusive breastfeeding failure in the research subjects. Firstly, breast milk has not come out, so it was encouraging mothers and families to give formula milk because they are worried the baby feels hungry. This condition indicates that there is still a lack of understanding of mothers and families about the nutritional needs of newborns in the first three days of life that will cause the baby does not get colostrum from breast milk.

Secondly, mothers who give birth in a hospital with a caesarian section or para-vaginal will be hospitalized separately. It contributes to the failure of exclusive breastfeeding because as long as the infant treated in the perinatology room, the health-care provider will give milk formula. The practices indicate that there is no support from the hospital to facilitate the infant's breastfeeding exclusively.

Thirdly, supplementary feeding is too early and too late. It indicates that the mother and family have not understood the right time to provide supplementary feeding. Supplementary feeding (pemberian makanan tambahan/ PMT) in the research subjects start at the age of 2 months to the latest at the age of 12 months. Giving liquids and foods other than breast milk to infants aged o-6 months will increase the risk of diarrhea and other diseases. Water and other liquids or foods may be contaminated, which can eventually cause diarrhea. Besides, the feeding process of babies fed or other foods at the age of $0-6$ months disrupted that milk production will decline. ${ }^{4}$ Supplementary feeding given at 12 months of age causes the baby to lack nutrients because, ideally, the breast milk supplementary administration begins at six months. In this research, some subjects get supplementary feeding of milk of more than six months and even 
have supplementary feeding of milk at the age of 12 months. The condition is bad for the growth of children because from the age of 6 months, children need additional food in addition to breast milk to support growth. Exclusive breastfeeding for 12 months or longer does not provide enough energy for infant growth. ${ }^{17}$

Fourthly, health workers recommend using formula milk. From all respondents who gave formula milk, two people stated that the formula feeding because the health officer suggested it. Another proves that there is no support even from health workers toward exclusive breastfeeding.

Health workers need to facilitate children to achieve healthy growth by facilitating every newborn to get exclusive breastfeeding. In addition to health, education is not only for the mother alone, but husband and family. They should also know the baby's nutritional needs early in life and the importance of exclusive breastfeeding to support children's growth.

Based on Table 2, the results of statistical analysis showed that there was no significant correlation between the completeness of immunization with stunting $p$ value $=0.376$. The results of this research are in line with the results of research which states that immunization status in children under five in rural and urban areas does not correlate with stunting with $\mathrm{p}>0.05$, 0.279 for rural area and 0.086 in urban area. ${ }^{19}$

Other researches have shown that children without a history of immunization have a 1.98fold higher chance of having stunting than a child with a history of immunization. ${ }^{20}$

Immunization is a way to increase a person's immunity actively against a disease so that when later exposed to the disease, they will not be sick or have only mild illness. Complete immunization has not guaranteed a child to avoid disease. To be able to provide protection is not only from the completeness of the provision of immunization but also from the quality of the vaccine and the way the vaccine storage. ${ }^{19}$ Complete immunization is not enough to guarantee child health, proper nutrition, and environmental health are needed to support children's health.

Based on Table 2 showed that there was a significant correlation between clinically healthy and stunting $\mathrm{p}$ value $=0.044$. Children with unhealthy conditions are clinically at 1.47 times greater risk of stunting compared to clinically healthy children.

A health complaint defined as a disruption to the physical or mental condition, including accidents, or anything else that disrupts daily activities. Meanwhile, someone is said to be sick if they have health complaint and it disturbs their daily activities. ${ }^{21}$

Illness in children harms children's growth. Diseases affect food intake, absorption, and utilization of nutrients that affect child nutrition. ${ }^{22}$ According to other studies, children who get sick a 0.6 chance of stunting compared with children who did get sick with a p value $<0.001 .^{23,24}$

In average, the toddler who suffers for 3-4 days of illness in the past month is one of the factors that keep their nutrition drained, so the growth becomes sluggish, and the low prevalence increases. Child disease increases the chances of malnutrition and stunting because when the child gets sick, usually the child's appetite will decrease so that it will affect the minimum intake of nutrition during illness. In addition to the condition of sick, the body is less useful in processing the food. If the child gets sick several times a year, the rate of growth will stop or slow down. The risk of malnutrition increases when diarrhea and other diseases further reduce the intake of protein, minerals and other nutrients that children need to stay healthy. ${ }^{18}$

The lack of nutrition occurs when the body does not get the amount of energy, protein, carbohydrates, fats, vitamins and minerals, and other nutrients in sufficient quantities. They are needed to keep organs and tissues staying healthy and functioning correctly. Protein-energy malnutrition (PEM) is still a significant public health problem. ${ }^{25}$

Based on Table 4, the stunting children, most had sufficient energy intake category that was 25 of 30 and only 5 of 30 with the category of less energy intake. The results of statistical analysis showed that there was no significant correlation between energy intake and stunting in aged 1224 months children with $\mathrm{p}$ value $>0.05$. Protein intake in stunting children mostly has a sufficient protein intake category of 53 of 60 (88\%) and only $12 \%$ with less protein intake category. The results of statistical analysis showed that there was no significant correlation between energy intake and stunting in children aged 12-24 months with p value $>0.05$.

The research results are in line with the results of the research in Sedayu subdistrict Bantul regency, which states that there was no significant correlation between the history of energy and protein intake with the incidence of stunting ( $\mathrm{p}>0.05)$. 
The subjects with adequate protein intake $63 \%$ had clinically unhealthy conditions, and the subjects with a sufficient energy intake $68 \%$ had clinically unhealthy conditions. In a sick condition, the process of absorption of food is less than the maximum. Abnormal absorption factors cause the nutrients that consumed cannot be absorbed entirely as in the condition of children having infectious diseases. ${ }^{19}$

Stunting in the working area of Singaparna Public Health Center is still a health problem. Children's health should increase to create maximum growth.

\section{Conclusion}

The determinant factors of stunting in children aged 12-24 months in the working area of Singaparna Public Health Center are gender and clinical health.

\section{Conflict of Interest}

The authors declare that there is no conflict of interest.

\section{Acknowledgment}

The researchers would like to thank the respondents and research subjects who have been willing to participate in this research. Acknowledgments also researchers submitted to the Tasikmalaya Regency Public Health Office and Singaparna Public Health Center, who has given the research permission.

\section{References}

1. Soetjiningsih, Gde Ranuh IGN. Tumbuh kembang anak. $2^{\text {nd }}$ Edition. Jakarta: EGC; 2016.

2. Indonesia Agency of Health Research and Development, Ministry of Health of Republic of Indonesia. Basic health research (Riskesdas) 2013 [Internet]. Jakarta: Indonesia Agency of Health Research and Development, Ministry of Health of Republic of Indonesia; 2013 [cited 2018 April 29]. Available from: http://labdata.litbang. kemkes.go.id/ccount/click.php?id=10.

3. Widanti YA. Prevalensi, faktor risiko, dan dampak stunting pada anak usia sekolah. JITIPARI. 2016;1(1):23-8.

4. UNICEF Indonesia. Gizi ibu dan anak.
Ringkasan Kajian. Oktober 2012 [cited 2018 April 30]. Available form: https:// bulelengkab.go.id/assets/instansikab/126/ bankdata/ringkasan-kajian-gizi-ibu-dananak-12.pdf.

5. World Health Organization (WHO). WHA global nutrition targets 2025: stunting policy brief. 2014 [cited 2018 May 1]. Available from: https://www.who.int/nutrition/ topics/globaltargets_stunting_policybrief. pdf.

6. Sandjaja, Poh BK, Rojroonwasinkul N, Le Nyugen BK, Budiman B, Ng LO, et al. Relationship between anthropometric indicators and cognitive performance in Southeast Asian school-aged children. Br J Nutr. 2013;110(Suppl 3):S57-64.

7. Rachmi CN, Agho KE, Li M, Baur LA. Stunting, underweight and overweight in children aged 2.0-4.9 years in Indonesia: prevalence trends and associated risk factors. PLoS One. 2016;11(5):e0154756.

8. Fuada N, Muljati S, Hidayat TS. Penentuan daerah rawan gizi berdasarkan analisis spatial. Media Litbangkes. 2012;22(1):18-29.

9. Dinas Kesehatan Kabupaten Tasikmalaya. Upaya peningkatan pelayanan kesehatan ibu dan bayi di Kabupaten Tasikmalaya. Paper presented at Seminar International STIKes Respati Tasikmalaya; 2017.

10. Dinas Kesehatan Kabupaten Tasikmalaya. Data bulan penimbangan balita berdasarkan indikator TB/U Kabupaten Tasikmalaya tahun 2016. Singaparna: Dinas Kesehatan Kabupaten Tasikmalaya; 2016.

11. Dinas Kesehatan Kabupaten Tasikmalaya. Cakupan ASI eksklusif dan BBLR Kabupaten Tasikmalaya tahun 2016. Singaparna: Dinas Kesehatan Kabupaten Tasikmalaya; 2017.

12. Nkurunziza S, Meessen B, Van Geertruyden JP, Korachais C. Determinants of stunting and severe stunting among Burundian children aged 6-23 months: evidence from a national cross-sectional household survey, 2014. BMC Pediatr. 2017;17(1):176.

13. Cruz LMG, Azpeitia GG, Súarez DR, Rodríguez AS, Ferrer JFL, Serra-Majem L. Factors associated with stunting among children aged $\mathrm{o}$ to 59 months from the central region of Mozambique. Nutrients. 2017;9(5):E491.

14. Maryunani A, Sari EP. Asuhan kegawatdaruratan maternal dan neonatal. Jakarta: Trans Info Media (TIM); 2013. 
15. Wandita KHDIS. Prognostic factors for normal postnatal growth rate in low birth weight infants. J Med Sci. 2012;44(1):72-7.

16. Alemu ZA, Ahmed AA, Yalew AW, Birhanu BS, Zaitchik BF. Individual and community level factors with a significant role in determining child height-for-age $\mathrm{Z}$ score in East Gojjam Zone, Amhara Regional State, Ethiopia: a multilevel analysis. Arch Public Health. 2017;75:27.

17. Millennium Challenge Account (MCA) Indonesia. Stunting dan masa depan Indonesia [Internet]. Jakarta: MCAIndonesia; 2017 [cited 2018 May 2]. Available from: http://www.mca-indonesia.go.id/ assets/uploads/media/pdf/BackgrounderStunting-ID.pdf.

18. UNICEF, WHO, UNESCO, UNFPA, UNDP, UNAIDS, WFP, the World Bank, Kementerian Kesehatan Republik Indonesia. Penuntun hidup sehat. $4^{\text {th }}$ Edition. Jakarta: UNICEF, WHO, UNESCO, UNFPA, UNDP, UNAIDS, WFP, the World Bank, Kemenkes RI; 2010.

19. Aridiyah FO, Rohmawati N, Ririanty M. Faktor-faktor yang mempengaruhi kejadian stunting pada anak balita di wilayah pedesaan dan perkotaan. JPK. 2015;3(1):163-70.

20. Picauly I, Toy SM. Analisis determinan dan pengaruh stunting terhadap prestasi belajar anak sekolah di Kupang dan Sumba Timur,
NTT. J Gizi Pangan. 2013;8(1):55-62.

21. Kementerian Pemberdayaan Perempuan dan Perlindungan Anak Republik Indonesia, Badan Pusat Statistik. Profil anak Indonesia 2018 [Internet]. Jakarta: Kementerian Pemberdayaan Perempuan dan Perlindungan Anak Republik Indonesia, Badan Pusat Statistik; 2018 [cited 2018 June 20]. Available from: https://www.kemenpppa.go.id/lib/ uploads/list/74d38-buku-pai-2018.pdf.

22. Mgongo M, Chotta NAS, Hashim TH, Uriyo JG, Damian DJ, Stray-Pedersen B, et al. Underweight, stunting and wasting among children in Kilimanjaro Region, Tanzania; a population-based cross-sectional study. Int J Environ Res Public Health. 2017;14(5):E509.

23. Fitri DI, Chundrayetti E, Semiarty R. Hubungan pemberian ASI dengan tumbuh kembang bayi umur 6 bulan di Puskesmas Nanggalo. JKA. 2014;3(2):136-40.

24. Darsene H, Geleto A, Gebeyehu A, Meseret S. Magnitude and predictors of undernutrition among children aged six to fifty nine months in Ethiopia: a cross sectional study. Arch Public Health. 2017;75:29.

25. Ubesie AC, Ibeziakor NS. High burden of protein-energy malnutrition in Nigeria: beyond the health care setting. Ann Med Health Sci Res. 2012;2(1):66-9. 